\title{
Using Quality Function Deployment Approach to Improve Logistics Service Quality in Trucking Operations
}

\author{
Teguh Bagus Surya*, Erlinda Nusron Yunus \\ Sekolah Tinggi Manajemen PPM \\ Jakarta, Indonesia \\ *teguhbagus.official@gmail.com, yunus.erlinda@gmail.com
}

\begin{abstract}
Service quality is one of the most important factors to achieve customer satisfaction. Some studies revealed that customer satisfaction leads to more customer retention and acquisition, especially in the competitive logistics industry. Improving service quality in logistics operations has been considered by a number of studies as a strategic initiative since the competition arises due to industry growth. This study aimed at analyzing the trucking service quality gap, determining the most critical service quality attributes, and developing strategies for service quality improvement through integration of Gap Analysis, Importance-Performance Analysis (IPA), and Quality Function Deployment (QFD). A case study was conducted at a trucking company headquartered in Semarang, Indonesia. The gap analysis showed that the all 18 service quality attributes had significant negative gaps. Then, IPA showed that a number of the 9 attributes should be prioritized, with 4 attributes in "concentrate here" quadrant and 5 attributes in "keep up the good work" quadrant. Through QFD, the 9 attributes were further translated into five strategic responses that need to be followed up accordingly by the company, namely "develop an independent QHSE division", “develop partnerships with ondemand trucking platform", develop an integrated transport management system", "develop a training center for truck drivers", and "develop a preventive maintenance system".
\end{abstract}

Keywords-service quality, gap analysis, importanceperformance analysis, quality function deployment, trucking

\section{INTRODUCTION}

Logistics industry plays a big role in contributing to the Indonesia's economy growth. Some logistics sub-sectors such as warehousing, transportation, and packaging contribute for the smoothness of goods and service distribution [1]. Reference Cargo reported from the Indonesia Statistics Agency (BPS) that logistics industry showed a significant increase in GDP from 2014 to 2018, with compound annual growth rate (CAGR) of $10.5 \%$ [2]. This growth gives huge opportunity for any companies that provide logistics services, especially in transportation.

Reference Word Bank also reported that Indonesia is the fifth in Asean in terms of Logistics Performance Index (LPI), after Singapore, Thailand, Vietnam, and Malaysia [3]. This index were based on some criteria, in which one of them is logistics service quality. In terms of competition in Indonesia itself, Reference Cargo mentioned that in 2018 there are approximately 6 million trucks and 1 million drivers in
Indonesia [2]. This resources come from various logistics firms, from individual vendors to large corporations. Hence, the data above showed that there's also potential for tight competition among Indonesia's logistics players.

According to Reference Meidute et al., since most companies tend to very competitive, they ought to deliver highquality service in order to stand out in the market and to make their customer satisfied and loyal [4]. Reference Gorla et al. suggest that service quality plays a role as the predecessor of customer satisfaction [5]. Reference Eklof et al., reported that customer satisfaction and customer loyalty positively influence on profitability, including Return of Assets (ROA), Return of Equity (ROE), Profit Margin, and operating income [6]. The report also concluded that the more satisfied customer is, the higher profitability become.

Many studies said that, there are 3 ways to develop competitive advantage in saturated market: Improving service quality, and increasing customer satisfaction and loyalty. Reference Parasuraman et al., developed the service quality model (SERVQUAL), followed by measurement model consisted of five dimensions (Tangibles, Empathy, Reliability, Responsibility, and Assurance) [7]. This model can be used to analyze the gaps between customer perceptions and expectations towards the service. This model has been used in various industries, including logistics. Some researchers adopt the model to be specifically applied in logistics, such as Bienstock et al., with Physical Distribution Service Quality (PDSQ) [8] and Thai with Logistics Service Quality (LSQ) [9].

Importance-Performance Analysis (IPA), developed by Martila and James [10], is used to categorize the most critical service quality into four quadrants, namely concentrate here, keep up the good work, possible overkill, and low priority. The service quality attributes are plotted onto the IPA matrix, in which the attributes located on the quadrant "Keep up the good work" are identified as the most important to improve and evaluated.

Quality Function Deployment (QFD) was first developed by Yoji Akao in 1966 while working in Mitsubishi's shipsyard. The QFD model has been widely used to translate the voice of customer into a number of technical responses towards product or service delivery in order to satisfy customers [11]. Although originally used in product development, the QFD model has been developed to design business strategy and planning [12]. 
QFD can be a useful tool to improve the service quality based on the gap analysis. According to RaVelle et al., QFD model has both tangible and intangible benefits in quality service improvement [13]. The translation process from the voice of customers into the technical or strategic responses uses a matrix called "The House of Quality" (HoQ), which metaphorically depicts the building of the QFD model.

The integration of gap analysis, Importance-Performance Analysis (IPA), and Quality Function Deployment (QFD) has been used in various industries, such as logistics [14], telecommunication [15], restaurants [16], banking [17], and manufacturing [18]. Therefore, the objective of this study is to developing strategies for improving logistics service quality through the integration of gap analysis, IPA, and QFD.

\section{METHOD}

The analytical framework (Figure 1) has two phases. The first phase is identifying the voice of customer by using Gap Analysis and Importance Performance Analysis. The second phase is developing strategies with quality function deployment.

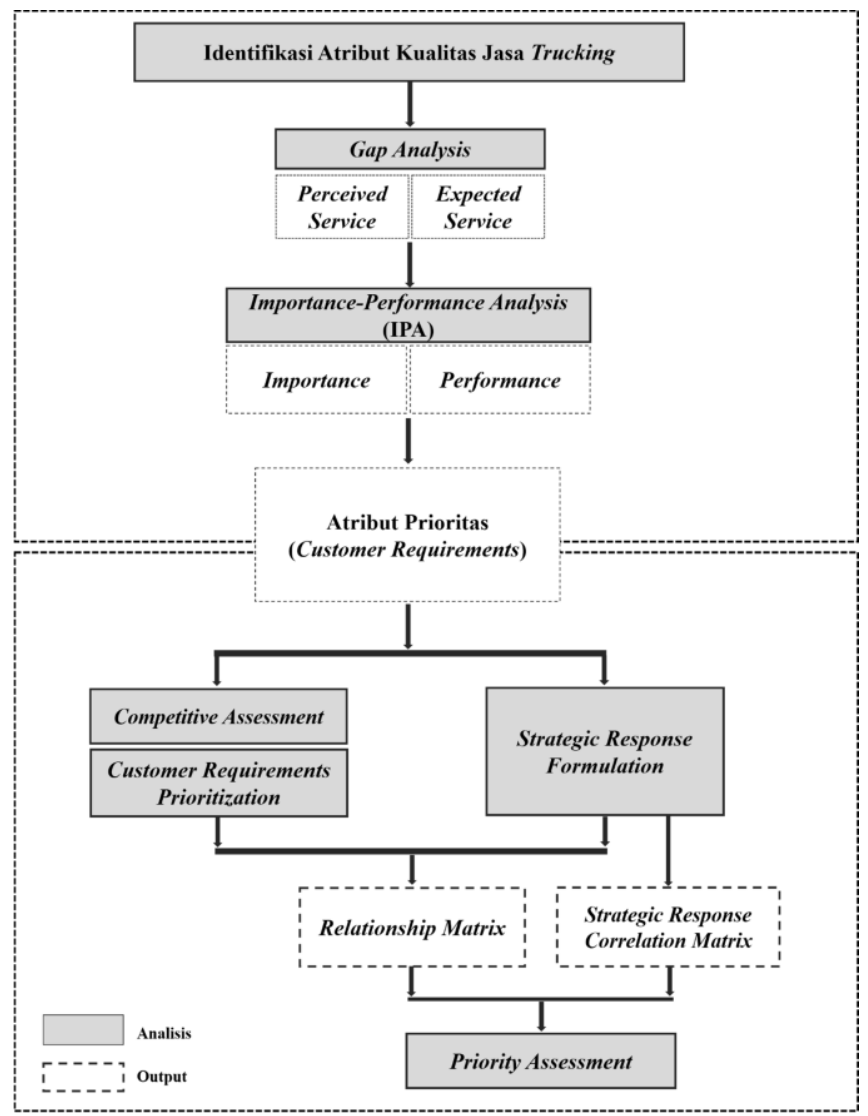

Fig. 1. Analytical framework.

This research was conducted using applied research approach, with the mixing of qualitative and quantitative design. A case study was conducted in a trucking company, ABC Logistics, headquartered in Semarang, West Java. The unit of analysis is the active corporate clients for the last 5 years. The sample was taken by purposive and convenience sampling, resulting in 48 samples. The samples were then used in online survey from December 2018 to January 2019. An interview was also conducted with a number of informants from the company to collect more data regarding the logistics service. The survey data were further analyzed with descriptive statistics using Excel and SPSS.

\section{RESULTS}

There are 18 logistics service quality attributes analyzed in this study, adapted from Thai [9]. In the Gap analysis (Figure 2 ), using the T-test at 5\% level, the results showed that all of the gaps between customer perception and expectation is significantly negative. This means that the clients were not quite satisfied yet with the logistics service provided by the company.

\begin{tabular}{|c|c|c|c|}
\hline Dimens & ion & Service Quality Attributes & Gap \\
\hline \multirow{5}{*}{$\begin{array}{l}\text { Customer } \\
\text { Focus }\end{array}$} & $\mathrm{CF} 1$ & $\begin{array}{l}\text { Staff's attitude and behavior in meeting customers's } \\
\text { satisfaction }\end{array}$ & $-0,800^{*}$ \\
\hline & $\mathrm{CF} 2$ & Responsiveness to customers' needs and requirements & $-0,644 *$ \\
\hline & $\mathrm{CF} 4$ & Staff's competence & $-0,578^{*}$ \\
\hline & CF5 & Handling customer's complain and claim & $-0,622 *$ \\
\hline & & Average & $-0,661 *$ \\
\hline \multirow{6}{*}{$\begin{array}{l}\text { Order } \\
\text { Fulfillment }\end{array}$} & OF1 & Order accuracy (meeting customers' requirements) & $-0,622 *$ \\
\hline & OF2 & Order condition (free of damage, fault or loss) & $-0,533 *$ \\
\hline & OF3 & Order discrepancy handling & $-0,489 *$ \\
\hline & OF4 & Consistence of service performance & $-0,600 *$ \\
\hline & OF5 & Safety and security in delivery & $-0,467 *$ \\
\hline & & Average & $-0,542 *$ \\
\hline \multirow{3}{*}{$\begin{array}{l}\text { Corporate } \\
\text { Image }\end{array}$} & $\mathrm{CI} 2$ & $\begin{array}{l}\text { Socially responsible behavior and concerns for human } \\
\text { safety }\end{array}$ & $-0,511^{*}$ \\
\hline & $\mathrm{CI} 3$ & Environmentally safe operations & $-0,556^{*}$ \\
\hline & & Average & $-0,533 *$ \\
\hline \multirow{5}{*}{ Timeliness } & TM1 & Total order cycle time & $-0,467 *$ \\
\hline & TM2 & Order placement convenience & $-0,378^{*}$ \\
\hline & TM3 & Transportation time & $-0,533 *$ \\
\hline & TM4 & Back-order time & $-0,533 *$ \\
\hline & & Average & $-0,478 *$ \\
\hline \multirow{4}{*}{$\begin{array}{c}\text { Information } \\
\text { Quality }\end{array}$} & IN1 & Application of IT and EDI in customer service & $-0,622 *$ \\
\hline & IN2 & Introduction of IT innovation in customer service & $-0,533 *$ \\
\hline & IN3 & Availability of order information & $-0,511 *$ \\
\hline & & Average & $-0,556 *$ \\
\hline
\end{tabular}

Fig. 2. Gap analysis.

Furthermore, the 18 service quality were further prioritized using Importance-Performance Analysis (IPA). The IPA matrix (Figure 3) was built using the modified data-centered, adopted from Deng and Pierskalla [19]. The service quality attributes were then distributed across the IPA matrix and categorized into the four quadrants. There are 4 attributes in the "Concentrate here", 5 attributes in the "Keep up the good work", 4 attributes in the "Possible overkill", and 5 attributes in the low priority. 


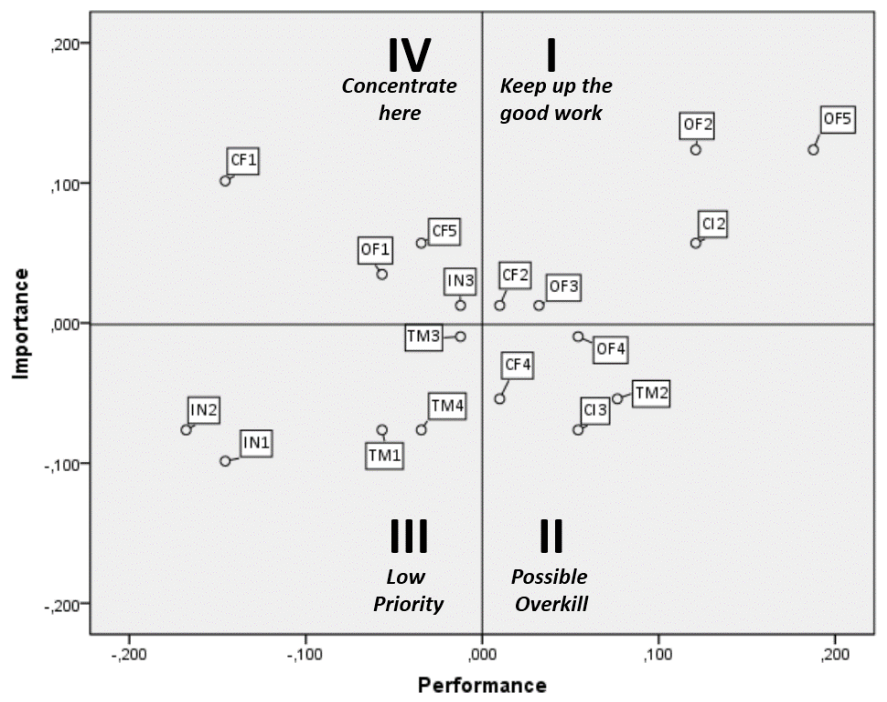

Fig. 3. IPA matrix.

Each quadrant demonstrates different improvement possibilities for the service quality. In the "Concentrate here", the attributes have high importance level but are low in performance. These attributes have the biggest negative gaps thus should be the number one priority to improve. The "Keep up the good work" quadrant shows the attributes that are already good both in importance and performance. Despite the relatively small gaps, the attributes performance should be maintained to avoid falling onto the "Concentrate here" quadrant. Furthermore, both "Possible overkill" and "Low priority" quadrant have low impact on the satisfaction thus there is no need for any improvement. Nevertheless, the company should keep monitoring the change of customer behavior to always be informed about how the service attributes affect the customer satisfaction.

The attributes located on the "Concentrate here" and "Keep up the good work" quadrant were further used as the prioritized customer requirements in the QFD model. These attributes will then be translated into strategic responses that should be implemented by the company. Based on the interview with some informants from the company, it was concluded that there were five strategic responses in regards to the customer requirements, namely 1) Developing an independent Quality, Health, Safety, and Environment (QHSE) division; 2) Developing integrated transportation management system; 3) Developing a training center for truck drivers; 4) Developing preventive maintenance system (PMS); and 5) Developing partnerships with on-demand trucking platform.

The relationships the customer requirements and the strategic responses for each item were assessed in the middle of the House of Quality (Figure 4), called the Relationships Matrix. The matrix could contain rating, comprising of $0,1,3$, and 9. The bigger the number the higher the relationship between two items. It also demonstrates the prediction of how high the strategic response will fulfill the customer requirements once it is implemented. Each strategic response was also examined among each other on the top of HoQ, or the roof, to find the trade-off between two strategic responses. This examination is important because of the limited resources the company has to implement the strategy. This "roof" tells the company which strategy is more critical over the others.

The next step is to examine the weight of each customer requirements. There are few components in this process, namely importance, goal, improvement ratio, and sales point. The Importance and Goal rating were obtained from the survey. Goal is the average score of expectation from each attributes. The improvement ratio is the ratio between Goal (Expectation) and Perception average score. It demonstrates how much the effort should be taken to achieve the customer expectation. The Sales Point was determined by assessing how well a service attribute can contribute to sales generation once it is fulfilled. The Sales Point consists of three level of rating: 1.5 (high sales potential); 1.2 (moderate sales potential); and 1.0 (no sales potential). Furthermore, the weight of each attribute can be determined through the calculation of Raw Weight and Normalized Raw Weight. Raw Weight is equal to [Importance x Improvement Ratio x Sales Point], while the Normalized Raw Weight is the ratio between Raw Weight and Total Raw Weight. The Normalized Raw Weight reveals the relative weight among the customer requirements.

After determining the weight for each customer requirements, the priority of the five strategic responses can be assessed. There are two components in the priority assessments: Contribution and Normalized Contribution. Contribution provides the ultimate measurement of how much each responses can improve the service quality. Contribution is calculated through the Equation 1 below:

$$
\text { Contribution }=\Sigma\left(i_{\mathrm{n}} \times \mathrm{j}_{\mathrm{n}}\right)
$$

$$
\begin{aligned}
\mathrm{i}_{\mathrm{n}}= & \text { Normalized Raw Weight of Attribute } \mathrm{n} \\
\mathrm{j}_{\mathrm{n}}= & \text { Numeric Value of Relationship Matrix } \\
& \text { Attribute } \mathrm{n}
\end{aligned}
$$

Normalized Contribution is the ratio between Contribution and Total Number of Contribution. Normalized Contribution reveals the relative comparison among the strategic responses, as shown below:

- Developing an independent QHSE division (25.59\%);

- Developing partnerships with on-demand trucking platforms $(22.66 \%)$;

- Developing an integrated transportation management system (21.98\%);

- Developing a training center for truck drivers (17.33\%);

- Developing a preventive maintenance system (12.44\%);

This results provide guidance for the company to prioritize on which strategy should be implemented first in order to improve the logistics service quality and optimize the customer satisfaction. 


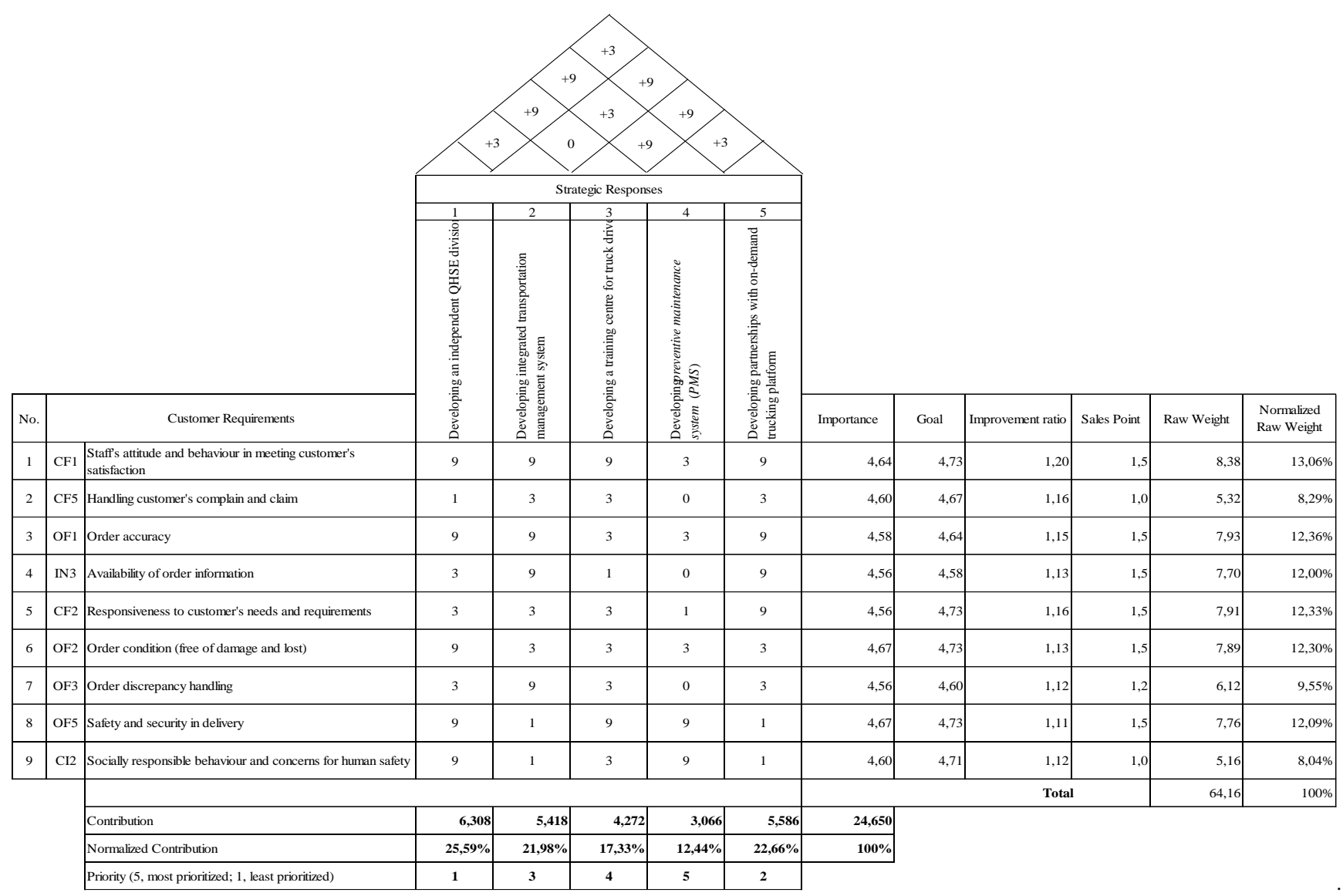

Fig. 4. House of quality.

\section{CONCLUSION}

This study showed that the integration of the three scientific methods, namely gap analysis, IPA, and QFD can provide powerful solutions to the improvement of the logistics service quality. The gap analysis provided a useful insight that all the service quality attributes are below customer expectations significantly. This result indicated that the company need to improve the service to meet the customer's standard. The next tools, IPA, categoized the service attributes into four quadrants based on different priorities. The four service attributes located on the "Concentrate Here" quadrant were the most priotitized, followed by five attributes located on the "Keep up the good work" quadrant. These attributes were considered the most important quality factors yet the performances need to be further improved.

The nine critical attributes were then translated into five strategic responses through QFD method. The responses were weighted according to their relationships and contributions to the service attributes thus it is considered that these response will be impactful to increase customer's satisfactions once they are implemented. With the prioritization applied, the company can properly allocate resources for the implementaion program and can improve the service quality effectively and efficiently.

The ever-changing customer needs in logistics industry demands the logistics providers to be more adaptive and responsive to the customer's expectation. Thus, the integrated method can be utilized simultanously.

\section{REFERENCES}

[1] A. Yunani, Perkembangan bisnis logistic Indonesia, 2017, [online]. Retrieved from https://supplychainindonesia.com/new/perkembanganbisnis-logistik-indonesia.

[2] K. Kargo, How Many Trucks Are There in Indonesia?, 2017, [Online]. Retrieved from https://www.kargo.co.id/artikel/h ow-many-trucks-arethere-in- indonesia/.

[3] World Bank, Connecting to compete 2016, trade logistics in the global economy: The logistics performance index and its indicators. Washington DC: The World Bank, 2018.

[4] I. Meidutè-Kavaliauskienè, A. Aranskis, dan M. Litvinenko, "Consumer satisfaction with the quality of logistics services," Procedia - Social and Behavioral Sciences, vol. 110, pp. 330 - 340, 2014.

[5] N. Gorla, T.M. Somers, and B. Wong, "Organizational impact of system quality, information quality, and service quality," Journal of Strategic Information Systems, vol. 19, pp. 207-228, 2010.

[6] J. Eklof, O. Podkorytova and A. Malova, Linking customer satisfaction with financial performance: an empirical study of Scandinavian banks. Total Quality Management \& Business Excellence, 2018.

[7] A. Parasuraman, V.A. Zeithaml, dan L.L. Berry, "A conceptual model of service quality and its implications for future research," Journal of Marketing, vol. 49, pp. $41-50,1985$.

[8] C.C. Bienstock, J.T. Mentzer, dan M.M. Bird, "Measuring physical distribution service quality," Journal of the Academy of Marketing Science, vol. 25, no. 1, pp. $31-44,1997$.

[9] V. Thai, "Logistics Service Quality: Conceptual Model and Empirical Evidence.," International Journal of Logistics: Research and Applications, vol. 16, no. 2, pp. 114 - 131, 2013.

[10] J.A. Martilla, dan J.C. James, "Importance-performance analysis," Journal of Marketing, vol. 41, pp. 77 - 79, 1997. 
[11] T.K. Chien, dan C.T. Su, "Using the QFD concept to resolve customer satisfaction strategy decisions," International Journal of Quality \& Reliability Management, vol. 20, no. 3, pp. $345-359,2003$.

[12] M.N. Walker, "Customer driven breakthroughs using QFD and policy deployment," Management Decision, vol. 40, no. 3, pp. 248 - 256, 2002.

[13] J.B. RaVelle, J.W. Moran dan C.A. Cox, The QFD Handbook. New York, NY: John Wiley, 1998.

[14] H. Santoso, "Meningkatkan kualitas layanan industri jasa melalui pendekatan integrasi metoda SERVQUAL-Six Sigma atau SERVQUAL-QFD,” J@TI Undip, vol. 1, no. 1, 2006.

[15] A. Darmawan dan F. Wurjaningrum, "Rancangan perbaikan kualitas pelayanan jasa dengan metode SERVQUAL, Importance- Performance Analysis, dan Quality Function Deployment pada Plasa Telkom Cabang Dinoyo Surabaya," Jurnal Manajemen Teori dan Terapan, vol. 7, no. 3, 2014 .
[16] Cheng, Chin-Chan, Ming-Chun Tsai, dan Shu-Ping Lin, "Developing strategies for improving the service quality of casual dining restaurants: ," new insights from integrating IPGA and QFD Analysis Total Quality Management \& Business Excellence, 26(3 - 4), 415 - 429, 2013.

[17] D.A. Kurniawati, dan M.L. Singgih, Integrasi SERVQUAL, IPA dan QFD sebagai sarana peningkatan kualitas pelayanan unit pembiayaan di bank syariah. Makalah dipresentasikan di Seminar Nasional Manajemen Teknologi XXIII, Program Studi MMT-ITS, Surabaya, 2015.

[18] S. Murali, S. Pugazhendhi dan C. Muralidharan, Integration of IPA and QFD to assess the service quality and to identify after sales service strategies to improve customer satisfaction - a case study, Production Planning \& Control, 2016.

[19] J. Deng dan C.D. Pierskalla, "Linking Importance-Performance Analysis, Satisfaction, and Loyalty: A Study of Savannah, GA," Sustainability, vol. 10, no. 704,2018. 